\title{
Creating Personal Learning Environments via Blogs
}

\author{
Pramela Krish (Corresponding author) \\ School of Language Studies and Linguistics \\ Universiti Kebangsaan Malaysia \\ E-mail: pramela@ukm.my \\ Noraza Zabidi \\ School of Language Studies and Linguistics \\ Universiti Kebangsaan Malaysia \\ Noorizah Mohd Noor \\ School of Language Studies and Linguistics \\ Universiti Kebangsaan Malaysia
}

Doi:10.7575/aiac.alls.v.4n.2p.29

Received: 05/04/2013

URL: http://dx.doi.org/10.7575/aiac.alls.v.4n.2p.29

Accepted: 05/06/2013

\begin{abstract}
Blogs are increasingly used in formal education to create personal learning environments, providing self-directed learners with more freedom, choice, and control over their learning. This paper will share findings of a study where students at the tertiary level were asked to commence blogs as a supplementary platform to engage in the learning of grammar where they could practise and learn specific grammar points shared by fellow course mates and instructors. The blogs also functioned as a learning diary where the students were asked to reflect on their use of grammar based on the weekly lectures and tutorials. A total of 20 year one students in the Foundation English course participated in this study. Data for the study was collected from the blog entries by the students and through in-depth interviews with them. The findings revealed that although the students were enthusiastic about engaging in the blogs, they are still not quite ready about personal learning environments.
\end{abstract}

Keywords: Blogs, formal education, learning grammar

\section{Introduction}

Teaching and learning grammar is often viewed as a difficult task for both teachers and students. For teachers the complexities of making students understand how the grammatical elements work is still a challenge. Teachers not only have to think of the right method to teach grammar elements but to prepare the right materials to teach to ensure that the learning takes place. What exercises do I set for my students to practise or as remedial work is also a common question. One would think that this happens at the primary and lower secondary schools but it is not alarming that students who enter the tertiary level too have problems with grammar elements. Many who join tertiary education lack the ability to write grammatically correct sentences and speak fluently.

With this scenario, grammar teaching becomes one of the central activities in any language programme. The idea that formal teaching of grammar benefits language learning is a generally accepted claim among the SLA community of practitioners and researchers (Borg \& Burns, 2008). Having said this, the teaching and learning of grammar is moving away from the traditional approach with the advancement of ICT. This is because with ICT student e learning can become a reality. It creates the flexibility to learn outside the classroom and this would make more sense especially when you have limited face-to-face time and weak students to handle. Students will have the freedom to select current issues whether local or global to be part of their grammar learning task. This is in tandem with what Ruzy Suliza Hashim (2011:89) states "I contend that what we teach in class - be it literature or languages - should coincide with issues that act in response to many burning problems in the world today".

The team of instructors for the Foundation English course, a compulsory course made students create blogs as a personal learning environment. In these blogs students can upload related materials on the grammar elements taught during the semester. The rationale for this being studies on students' perceptions on using blogs in the classroom have demonstrated positive feedback where students found blogging to assist in understanding course content and were motivated with the feedback received from their peers and teachers. Although the review of literature indicates that most studies on the effect of blogs have focused on language skills, specifically writing, few have looked at learning grammar. Hence, as instructors we strongly felt that the integration of blogging as a compulsory component into the course is important as the 
rationale was to provide an additional platform for students to master grammar skills. Through authentic materials from open sources, students can have more practice thus promoting active learning. This is also to enable students to learn as a community by collaborating with course mates, and this promotes learner autonomy. This paper reports how the students actually perceived this blogging activity and will share some of the grammar elements in the blogs.

\section{Literature Review}

Currently research concerning English grammar points out to the same aspects for effective grammar learning. Grammar needs to be learnt as a holistic system in a relaxed atmosphere. The learning experience should reduced anxiety and enhanced learners' involvement (Thekes, 2013). An important element for learners is to be interested and motivated in the visual stimulus which can be found in pictures. Mumford (2008) states that learning should involve visuals for effective grammar learning as they can stimulate senses. The availability of these in this era of advanced technology allows this learning experience to address learner needs. This is so with the wide use of blogs in the World Wide Web (WWW). It is also suggested that technology can create an innovative online grammar resource for learner awareness of grammatical functions in a fun way (Hafner \& Miller 2011).

The concepts which are the backbone of learner autonomy have been promoted in the literature and attracted language teachers and learners alike. This is due to the movement towards more communicative pedagogical approaches encouraging students to be more responsible for their own learning (Miller, 2009). Learner autonomy has been defined as the ability to take control over one's learning (Holec, 1988) and has elements of detachment, decision-making, reflection, and independence (Little, 1991). However, it must be noted that learner autonomy brings different meanings to different people

(Sinclair, 2006)

Learner autonomy is often mistakenly equated solely with independent out-of-class learning in which learners are in control of all aspects of their learning process. In this view, an autonomous learner is one who is intrinsically motivated and learns outside the classroom, alone, and with no need for support from the teacher. However, learner autonomy can also develop in the structured learning environment of the classroom and become part of the pedagogical objectives of a language course. Less independent learners can be encouraged to reflect on their learning and ways to improve it (Little, 1997).

Experience is a central notion to the constructionist theory as "knowledge can and can only be generated from experience" (von Glasersfeld, 2000, p. 4). Adopting such a theoretical approach to course design, the student is viewed as an active agent who brings his or her unique learning characteristics to the social learning context.

Green, Facer, Rudd, Dillon and Humphreys (2005) put forward four points to meet the criteria of personalised learning. Pedagogy must

- allow learners to make educational decisions of their own;

- $\quad$ accept the students' different forms of skills and knowledge;

- create diverse learning environments; and

- encourage learners' feedback and assessment.

Siemens (2007) further stresses that the environment must be personalised using learning tools enabling openness, interoperability and learner freedom. Correspondingly, Downes (2005) further describes the need for an environment which protects and enables identity creation, enhances our natural need to socialise, and builds learning communities of inquiry. In short, the role of the individual in organising, and shaping a learning environment is paramount for effective learning.

Personalised websites or blogs are new forms of expressions linking blog writers with other people interested in the same area of specialisation (Mc Lellan ,2006). Blogs is a vital tool in education particularly in language learning. (Song \& Chan, 2008; Galien \& Bowcher, 2010). When discussing educational and thought content, blogs are found to be based on humanistic methods enabling freedom in writing for self-expression. Thus, teachers can be deeply involved as they give feedback to students. (Eastment, 2005; Zhang, 2009). Besides this, they are genuine and allow meaningful communication utilising actual interactions. In addition, for students with less confidence, they encourage motivation, self-expression and thought. (Hanson-Smith, 2001).

According to Oravec (2003) blogging plays a crucial part in community building, for thought sharing about issues and projects. Ultimately, net citizens are developed and they become actively involved in communication and relationships. Besides this, they develop a strong need to belong and create an identity. In line with the social constructivists, learners can share and face challenges together and learn in their own social network. The positive outcome of blogs includes personal knowledge construction consisting the elements of coaching, modelling, reflection, articulation, scaffolding, and exploration (Loving et al. 2007).

There has been a need among educators to utilise blogs in language classrooms. Research found that student perceptions of blogs were usually commendable when understanding concepts (Ellison \& Wu, 2008). Due to the important need in communication that is between teachers and students and among students, there has also been a significant increase in interest and motivation (Pinkman, 2005). There have also been positive results when incorporating blogs into writing among ESL and EFL learners (e.g. Ellison \& Wu, 2008; NadzrahAbu Bakar\&Kemboja Ismail, 2009).

Students play multiple roles as writers and readers when they blog, and are involved in communication actively as they interact. This is why university students have the opinion that blogging fosters learner autonomy, language skills and 
motivation (Pinkman, 2005; Harwood's, 2010). Blogs are effective tools as agents of learner autonomy as they allow personalisation of ideas and responses for example in the case of on-line diaries. They help students to be aware of interaction and be autonomous as they edit their work together. They also become motivated as they ensure their blogs are attractive so that their friends would visit their blogs (Bhattacharya \& Chauhan, 2010). In short, blogging in learning is motivating, challenging, adaptable, and easy to execute, and promotes autonomous learning.

This research needs to be undertaken as there should be a study on learners' views concerning the integration of learners' actual interaction using social media with their learning experience. This is apt particularly with the advent of ICT in the students' daily lives. Learning in classrooms should not be a separate activity but connected, linking social activities with their learning experience. Due to the complex nature of grammar, there is a need to study the perceptions of utilising blogs as a means of sharing ideas, solving problems, promoting autonomous learners as they personalise their blogs about grammar. Besides this, learners should redefine their roles as passive learners in the past and become more active in creating dynamic learning communities. Very few studies have examined the students' perceptions of this type of learning for English grammar. Thus, the effectiveness of blogs in learning grammar for students at the tertiary level needs to be examined.

\section{Methodology}

The total number of students in the sample was 65 comprising 43 females and 12 males. From the total, forty eight students were categorised under Band Four in their MUET (Malaysian University English Test) whereas sixteen were under the Band 3 category. One student was from Band Five. Besides this, the remaining students obtained English Language qualifications from the Foundation Course (Asasi) and Diploma in TESL. The MUET is the assessment which is compulsory for those who want to join tertiary education.

As an initial step to conduct this action research, a survey was carried out with all 65 students from the Foundation English course (SKBE1003). This group consisted of BA ELS and B ED (TESL) students in their first semester at the National University of Malaysia (UKM). An open-ended questionnaire comprising 3 sections (Background Information, Learning Grammar, Integration of Technology in learning English and Blogging experience) was distributed to students. Next, a briefing cum training session was given to all students on the setting up of blogs using Wordpress.com. This task was incorporated into the course. Students' blogs are linked to their colleagues and respective lecturers of the course. Besides, these blogs played the function of a learning diary where the students were asked to reflect on their use of grammar based on the weekly lectures and tutorials. The students' progress of the blog activities can be monitored by the instructors and consultations with lecturers are arranged if needed.

Before an in-depth interview with the selected students was carried out, students' blogs were assessed by their respective lectures according to criteria set (refer to Table 1). Subsequently, the students were categorised into two groups - active and non-active.

Table 1. Assessment table for blog task

\begin{tabular}{|l|l|l|l|l|l|l|}
\hline & & & & & & Total/comments \\
\hline $\begin{array}{l}\text { Frequency of } \\
\text { postings }\end{array}$ & 1 & 2 & 3 & 4 & 5 & \\
\hline $\begin{array}{l}\text { Relevance of } \\
\text { Contents }\end{array}$ & 1 & 2 & 3 & 4 & 5 & \\
\hline $\begin{array}{l}\text { Collaborative } \\
\text { efforts }\end{array}$ & 1 & 2 & 3 & 4 & 5 & \\
\hline Creativity & 1 & 2 & 3 & 4 & 5 & \\
\hline TOTAL & & & & & & \\
\hline
\end{tabular}

Initially twenty students agreed to be interviewed but due to time factor, only five students from each category who volunteered were interviewed.

The interview data was analysed qualitatively and reported in the section that follows.

\section{Findings and Discussion}

Below are selected samples of how students personalise their blogs with the choice of colours, image, name etc. 


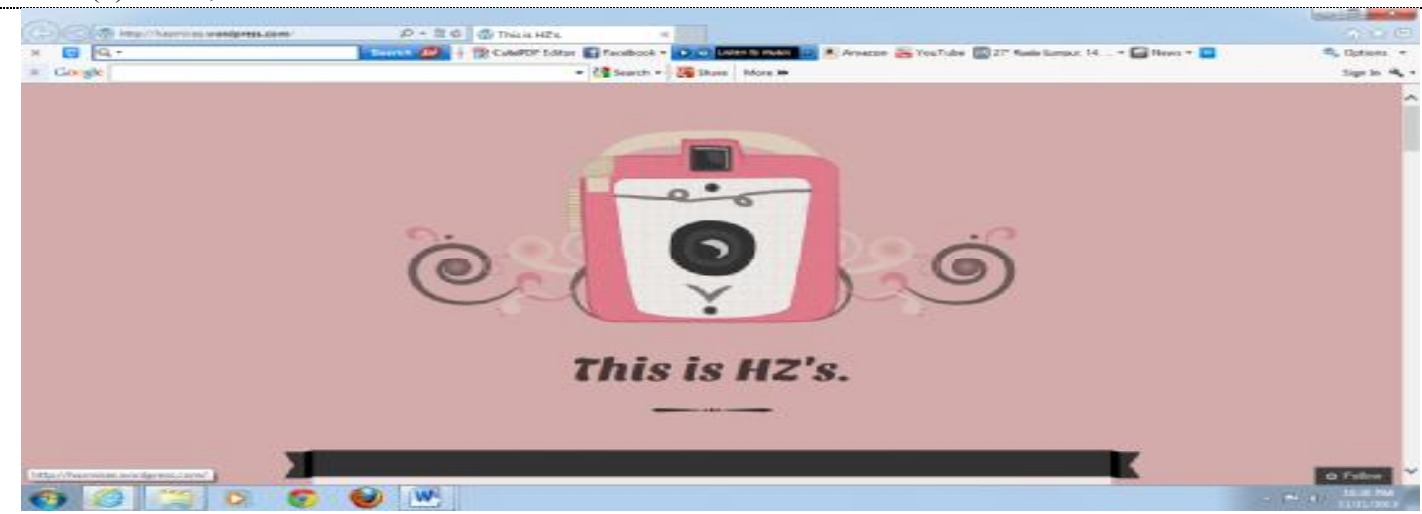

Sample 1

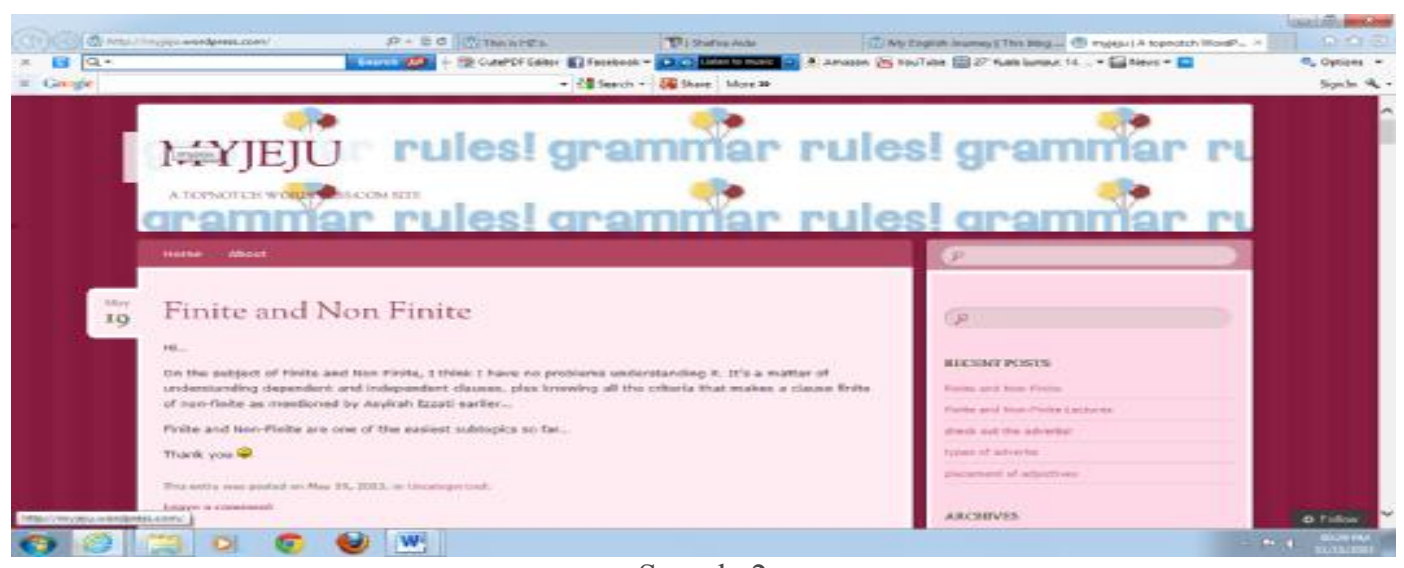

Sample 2

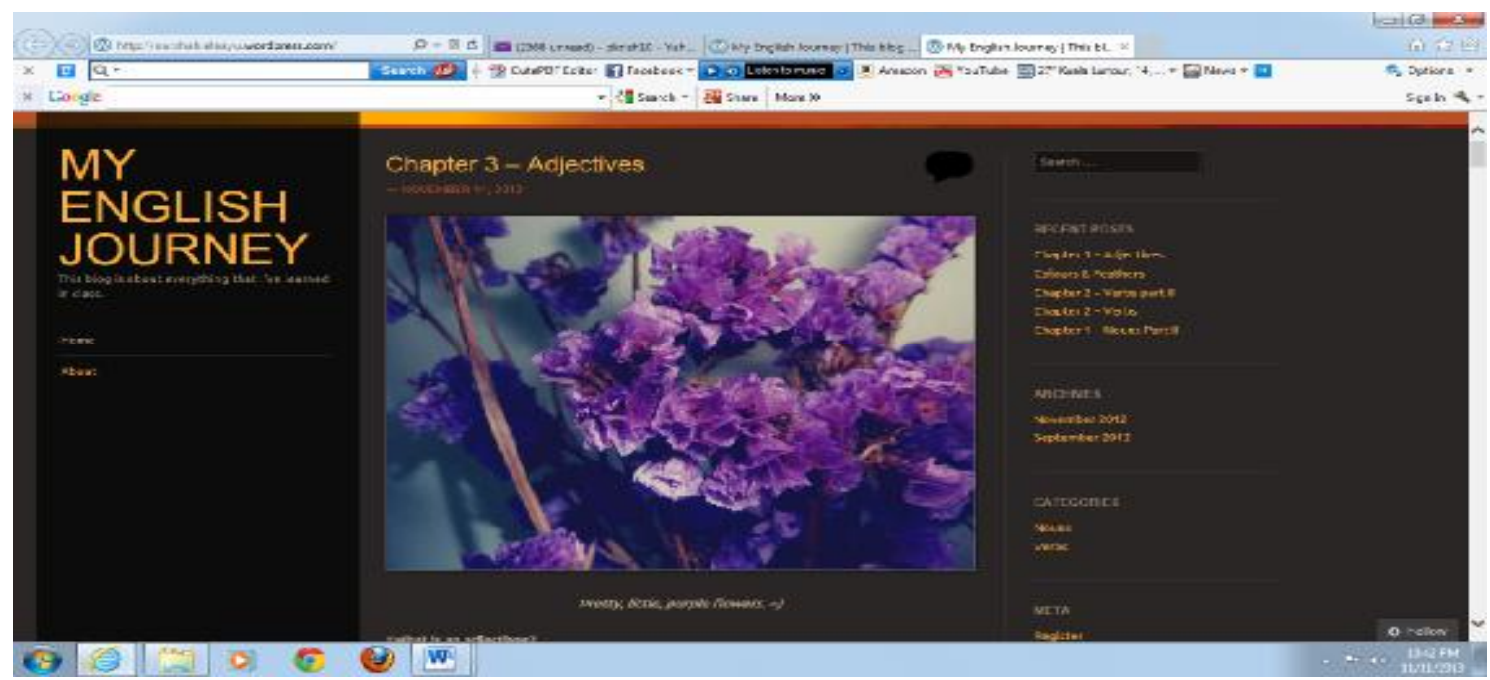

Sample 3

Some of the weekly postings according to topics are illustrated below.

1. The names given by my parents is Nurjannah Binti Mohammed Ghouse

I love it but there's to many people with the name of Jannah, so my friend decided to call me $\mathrm{Nj}$.

Nurjannah the initial of my name.

Then paralleled with the development of the world it turns out to become Enjay.

[SGGS ]. St. George`s Girls School was my high school until I further my studies at UiTM Shah Alam for Foundation Of Law.

I'm from PENANG and I'm proud of it because I love my hometown so much

2. That's a little bit of me

3. I'm not PERFECT but part of me is EXCELLENT so feel free to know me 


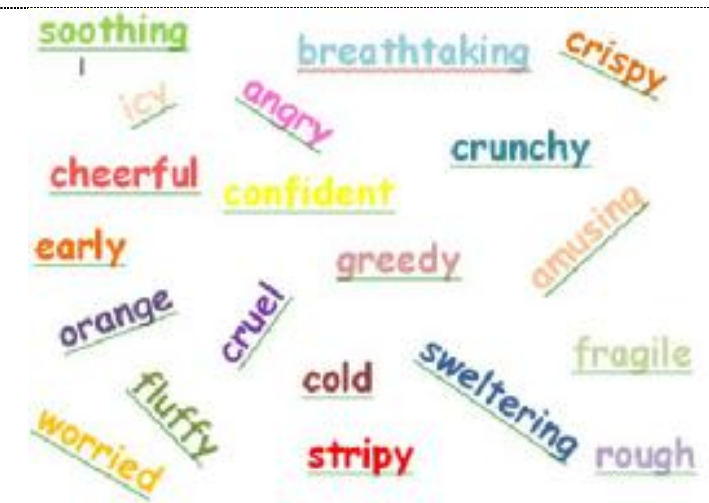

Do you know what Adjectives are? Adjectives are describing words (like good, beautiful, or blue) which are usually used with nouns (like person, flower or sky)

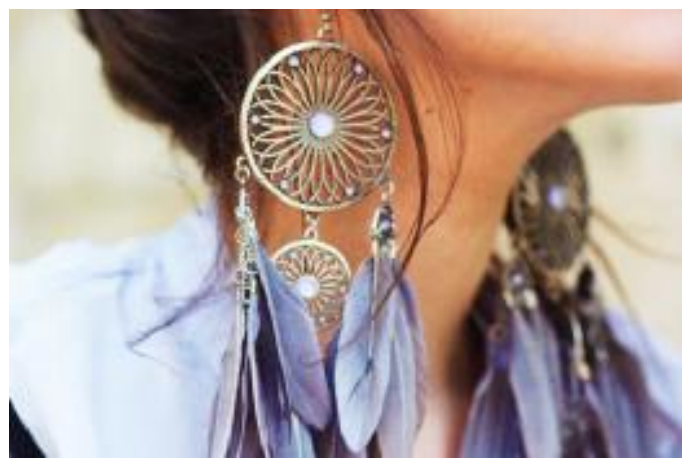

Unique and exotic feather earrings $=$ )

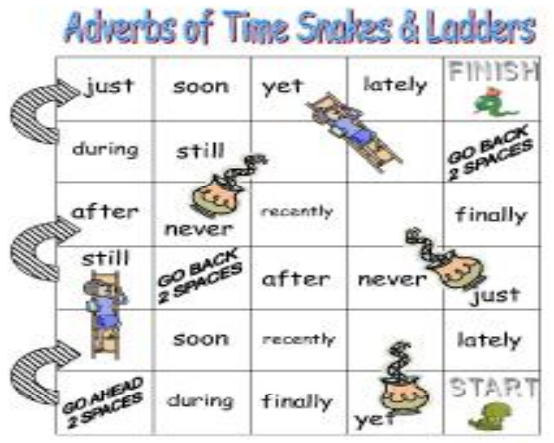

tom

inser $=$

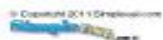

http://www.youtube.com/watch?v=iN5wzv5M-no\&feature=plaver embedded

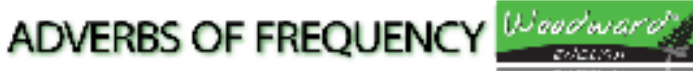

\begin{tabular}{|c|c|c|}
\hline \% & Adverb of Frequency & Example \\
\hline $100 \%$ & Alivays & I a ways study after clas: \\
\hline $90 \%$ & Usually & I 」sually walk to work \\
\hline $80 \%$ & Normally / Generally & I hormally get good marks \\
\hline $70 \%$ & Often / Frequently & I often readin ted at right \\
\hline $50 \%$ & Sometimes & I somet mes sing in the shower \\
\hline $30 \%$ & Occasionally & I ascasionally yo ts: bed late \\
\hline $10 \%$ & Seldom & I seldom put salt an my food \\
\hline $5 \%$ & Hardly ever / Rarely & I hard y -ver get angry \\
\hline $0 \%$ & Never & Vegetarians never eat meat \\
\hline Subj & Adverb + Main V & $\begin{array}{l}\text { Subject + BE + Adverb } \\
\text { He is d woys r aspy. }\end{array}$ \\
\hline
\end{tabular}




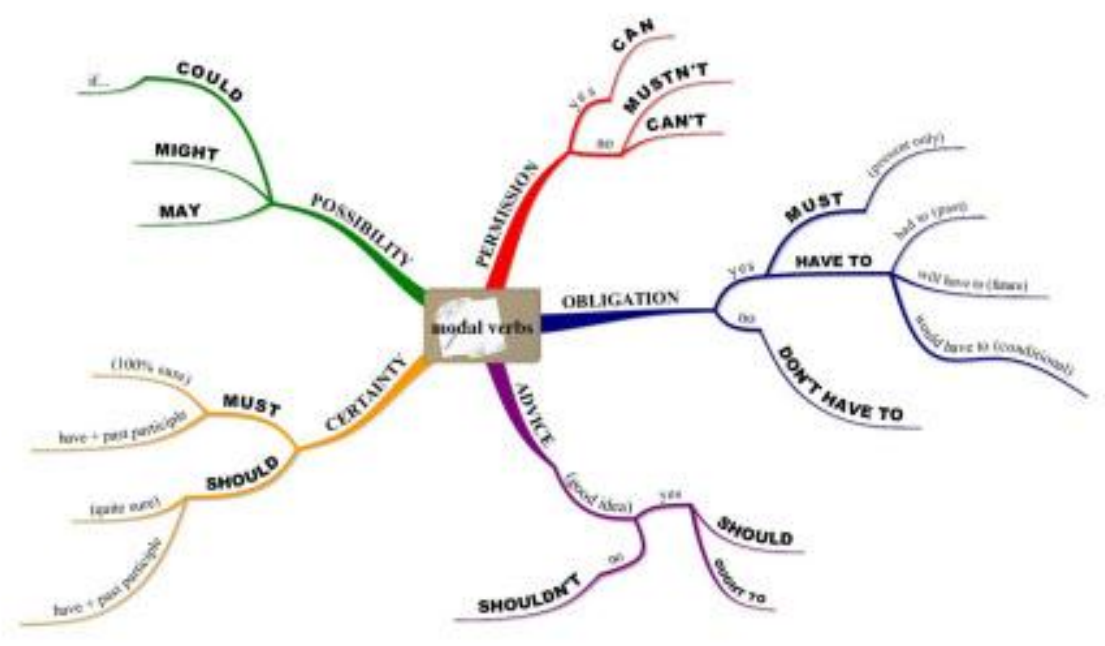

\section{Usefulness of the blogs}

Some students had negative opinions of blogs preferring other methods. These students with these sentiments were weak students who were negative about the subject rather than the blog as a learning tool. Students felt that more flexibility could be given to students to choose their preferred blog spots either blogspot or wordpress. This would have reduced unnecessary stress for them when undergoing the tasks. The instructions should also be more stringent emphasizing creativity and not merely uploading materials. This is to ensure that students are evaluated more fairly as some had put more effort to be creative as compared to others. In short, it would seem that students did not have complaints about the implementation of the blogs per se, merely the criteria and imposition of certain blog spots.

\section{Student M}

I don't think it is useful because there are many effective ways other than blogs and blogs are outdated. There are some students who still have blogs but personally I don't like Wordpress cause if it was blogspot it would have been easier la...

What they did was they copied and pasted on the blog from online so where is the learning... they just put everything in just to get marks so I don't think it was effective.

Student H:

promotes plagiarism and it allows them to copy and paste work online and even their friends work on the blogs.

No. and they asked us to do it in a creative way like putting in a video and all but see it is still plagiarizing cause it is still someone elses video and all.

\section{Student N:}

From my point of view I did not finish my blog because I found it hard to work on Wordpress... I am not tech savy and so it was hard for me to use it. I did try to get my friends to help me but they all said that they did not know how to use wordpress and they only knew how to use blogspot so I found it troubling for me to try to learn how to use wordpress. In terms of learning English... I have been learning English from the TV from my mom and I did not see the relevance of the blog...

I'd rather learn from books and people rather than blogs...I don't see the need for blogs to improve my English. 
Student J

I don't love writing, I hate writing especially about grammar and the foundation thing is about grammar so it does not make me interested to do the blog.

.... because I am a person who is not interested in .... I didn't even open my Facebook... you can ask him, I did not even put any comment yet on the Facebook group.

\section{Learning experience}

In terms of learning experience, the students felt that blogging is useful as they see blogging as a means of sharing knowledge and to some extent peer correction can be done with less inhibitions with blogs as a learning tool. This is so as it is not done in class with all students and instructor, listening to their mistakes during face- to- face meetings which can be quite embarrassing. Besides that students can check their facts first by referring to sites or books before writing out ideas or posting activities in their blogs.

\section{Student $K$}

I think it is useful in some way cause when students reflect on the course, his fellow classmates can comment whether if his understanding is wrong or not because it's about sharing and if we see something that is not correct on our friends' blog we can comment to tell him if there is some correction...

\section{Timespent}

The time spent on blogs differs among the students depending on their IT skills and knowledge. Besides this, the students' discipline in terms of their time management affects the length of time they spent on the blogging activity. For those who are familiar with wordpress or blogging, they do not need much time to post their entries as compared to those who are not. Thus, the time spent ranges from fifteen minutes to 1 hour. Also, it can be stressful for those who tried to catch up with the blog tasks by reading their colleagues' posts to respond and doing more than five posts at the same time. In addition the quality of the post would also be affected negatively if the students attempted to read many of their friends' posts or to post multiple postings in a short period of time as there would be less time for reflection and creativity. To solve this problem, the instructors should constantly assess the blogs for students' scores quarterly (every three weeks) so that students will not leave their work up till the last minute and rush to produce multiple posts at a time. Instructors need to provide samples of the posts that have high quality (which are reflective and creative) and check on the students' work constantly and give feedback to ensure actual learning takes place.

\section{Student N}

here because Bidin our peer said that it only took him about 15 minutes to finish one entry but for me it wasn't the same cause it took me like 1 hour to finish one entry because I was not familiar with wordpress so it is hard and then it is very pressuring.

\section{Student $\mathrm{H}$}

when I did the one entry blog I did it with my own idea so maybe now people won't feel the burden to post every week maybe they can just post 1 or 2 times and that's it. Because I piled up the work and in the end near the deadline I felt pressure cause I had to put in not cause I want to.

\section{Student M}

There were a lot of links posted in our coursemates blogs but I did not have time to see all the links just one or two.

\section{Student K}

and since there is no exact dates lecturer check the blog so I think it is okay for me to postpone the writing and one shot do it at the end of the semester. 
It would seem that the blogging culture for academic purposes have not really been popular among the students. Even though blogging should support reflections, sharing, and the building of learning communities; for this course students are slow in sharing, discussing to solve problems and giving opinions or comments. They do not see the blogging task as having a social function for educational purposes. In contrast, students seem to have instrumental motivation rather than utilizing blogs for integrative reasons. They are of the opinion that their own comments are not creative, nor good enough for responses from their peers.

\section{Student N}

I only had one friend following my blog and I won't blame them...

\section{Student H}

Lack of interest to write comments on friends' blogs

Student J

thing because we are judging the person personality based on this.

Student K

we don't write cause we are not inspired to and even if we write there is nobody to read...

\section{Instructor support}

The instructors' support is an essential factor for students to put more effort in using the blogs in an effective way. This support is also needed in order to encourage the students to spend more time on the blogs efficiently. Instructors may feel that students need to be more autonomous and be given more freedom to use the blogs. However, the comments from the students suggest that they still need constant feedback from the instructors in order for them to feel encouraged that they are on the right track; doing what they need to do and meeting the requirements of the course.

\section{Student K}

I think another reason why I did not post anything because I think my lecturer did not review my blog if the lecturer keep asking in the class about the blog and keep checking... then the students will keep writing on the blog.

The involvement of the lecturers can be like an inspiration for the students to keep writing, when they see the lecturers' comments.

\section{Contents and information uploaded}

We also analysed the students' blogs in terms of type of materials uploaded in relation to the grammatical component chosen, the engagement with the text, and the grammatical component uploaded. This kind of micro analysis showed not much writing in terms of feedback by course mates. Students only managed to upload interesting information without actually showing their engagement in the learning.

The students lacked confidence that they can produce creative blogs and interesting entries. A solution for this may be to show some very good entries by pointing out what are some of the criteria they possess which categorised them as 'good'. In short, the students need to know the expectations of the instructors in terms of the quality (in terms of reflections and creativity) of the contents posted.

Student H

In terms of ideas we were lacking but most times people already did it so I don't bother putting it up. The only entry I did was different compared to the others. 
Student N

Mine was on the same topic and it was plagiarized because I could not trust myself to write a good entry on nouns so I took most of it from google... it was really boring...

Student N

I think what he is trying to say is that he has no ideas on how to make it more interesting and creative... most of us copy from the internet and the lecture notes itself and then make it.... so basically it's just the same... all of us.

\section{Conclusion}

The findings confirm that the students of this course illustrated poor capability when incorporating technology with learning. Furthermore, it is unexpected that the students faced much anxiety and stress using technology even though they are from the net generation. This may be because they only use the internet for social reasons rather than for academic or educational purposes. Parallel to this, many learners face difficulties in grammar especially writing. This difficulty may be because English is not their first language and the course is very technical, thus affecting students' interest. However, blogs can be utilised as a grammar learning platform to make learning grammar less technical as it enables sharing and solution seeking in a collaborative way. The way to do this is to have more detailed explanations and quality entries by instructors so students can be clear of the type of entries expected of them. This move will also give confidence to students when they post their entries. Moreover, there should be more involvement from the instructors by giving constant regulated feedback. Besides this, more samples of quality blogs need to be shown to the students. With the right blend of feedback, support and explanations by instructors, students can engage in the learning in a creative way.

Another factor as to why students may not show as much enthusiasm in using blogs in the course could be caused by the user interface. A number of students stated that Wordpress was indeed not user friendly which in return takes up a lot of their time when blogging. Hence, if blogging platforms are chosen by the instructors, students need to be guided closely on the operational methods of the selected platform.

\section{Acknowledgement}

This research is funded by Universiti Kebangsaan Malaysia (PTS 2012-114).

\section{References}

Atanu, B. \& Kiran, C.(2010). Arguementing learner autonomy through blogging. ELTJ 64(4) 376-384.

\section{Doi:10.1093/elt/ccqoo2}

Borg, S.,\& Burns, A. (2008) "Integrating Grammar in Adult TESOL Classrooms", Applied Linguistics. 29.3: 456-482.

Downes, S. (2005). E-learning 2.0. eLearn Magazine, Oct.

http://www.elearnmag.org/subpage.cfm?section $=$ articles\&article=29-1

Eastment, D. (2005). Blogging.ELT Journal. 59 (4), 358-361. http://dx.doi.org/10.1093/elt/cci073

Ellison, N., \& Wu, Y. (2008). Blogging in the classroom: A preliminary exploration of student attitudes and impact on comprehension. Journal of Educational Multimedia and Hypermedia, 17(1), 99-122.

Galien, P., \&Bowcher, W. L. (2010).Using Blogs in ESL/EFL Teaching and Teacher-Training.Asian EFL

Journal.Professional Teaching Articles.Vol.42, February.von Glasersfeld, E. (2000). Problems of constructivism. In L. P. Steffe \& Thompson, P. W. (Eds.), Radical constructivism in action (pp. 3-10). New York: Routledge.

Green, H., Facer, K., Rudd, T., Dillon, P. \& Humphreys, P. (2005). Personalisation and digital technologies. Bristol: Futurelab. [viewed 17 Oct 2009] http://www.futurelab.org.uk/resources/documents/opening_education/Personalisation_report.pdf

Hafner A.C and Miller,L.Fostering Learner Autonomy in English For Science: A Collaborative Digital Video Project In A Technological Learning Environment http://ltt.msu.edu/issues/october2011/hafnermiller.pdf October 2011, Language Learning \& Technology Volume 15, Number 3 pp. 68-86 Copyright (C) 2011, ISSN 1094-3501 68

Hanson Smith, E. (2001). Computer-assisted language learning. In R. Carter, \& D. Nunan (Eds.), The Cambridge guide to teaching English to speakers of other languages (pp. 107-113). Cambridge, UK: Cambridge University Press, fromhttp://dx.doi.org/10.1017/CBO9780511667206.016

Harwood, C. (2010). Using blogs to practice grammar editing skills. English Language Teaching World Online, 2, 1-13.

Little, D. (1991). Learner autonomy 1: Definitions, issues and problems. Dublin: Authentik.

Little, D. (1997). Language awareness and the autonomous language learner. Language Awareness, 6(2/3), 93-104.

Mc Lellan, H. (2006). Digital storytelling in higher education. Journal of Computing in Higher Education, 19(1), 65-79 
Miller, L. (2009). Reflective lesson planning: Promoting learner autonomy in the classroom. In R. Pemberton, S. Toogood, \& A. Barfield (Eds.), Maintaining control: Autonomy and language learning (pp. 109-124). Hong Kong: Hong Kong University Press.

Mumford, Simon. (2008). 'Picture This!' Modern English Teacher, 17(2) pp. 40-42

Nadzrah Abu Bakar\&Kemboja Ismail.(2009). Using Blogs to Encourage ESL Students to write constructively in English.AJTLHE, 1(5), 45-57.

Oravec, J. A. (2003). Weblogs as an emerging genre in higher education.Journal of Computing in Higher Education, 14(2), 21-44.

Pinkman, K. (2005). Using Blogs in the Foreign Language Classroom; Encouraging Learner Independence.The JALT CALL Journal, 1/1, 12-24

RuzySuliza, H. (2011). Inculcating Social Activism in the Literature Classroom 3L: The Southeast Asian Journal of English Language Studies. 17 (Special Issue).89 -97.

Siemens, G. (2007). PLEs - I acronym, therefore I exist. elearnspace: learning, networks, knowledge, technology, community [weblog], 15 Apr. [viewed 13 Jun 2009]. http://www.elearnspace.org/blog/archives/002884.html

Sinclair, B. (2006). Multiple voices: Negotiating pathways toward teacher and learner autonomy. In T. E. Lamb \& H. Reinders (Eds.), Learner and teacher autonomy: Concepts, realities and responses (pp. 237-268). Amsterdam: John Benjamins.

Song, H., \& Chan, Y. (2008).Educational blogging: A Malaysian university students' perception and experience. Proceedings ascilite Melbourne.

Thekes, J (2013).Grammar Games with Students' Total Physical Involvement. http://ihjournal.com/grammar-games with students

Zhang, D. (2009). The Application of Blog in English Writing. Journal of Cambridge Studies, 4(1). 